\title{
Effect of Employees' Commitment on Organizational Performance in Selected Firms
}

\section{| Ogala S. C |}

\author{
School of General Studies, \\ Department of Arts and \\ Humanities, Delta State \\ Polytechnic Ogwashi Uku, \\ Delta State, Nigeria
}

anthony.kifordu@yahoo.com

\begin{abstract}
This study investigated the effect of employee's commitment on organizational performance in selected brewing firms. Two objectives which are ;To examine the impact of employee commitment on organizational profitability in brewing industry in Nigeria To examine the dimensions of employee commitment on performance in brewing industry in Nigeria guided the study. Also two research questions and hypotheses were drawn along that line. A survey design was adopted with a sample population size of 216 drawn using Taro Yamani. Data were presented and analyzed using tables and simple percentages. Also, hypotheses were tested using parametric statistics. Findings revealed that Organizational profitability had a positive influence on employees performance in the area studied $(Z c=4.226>Z t=1.645)$ and Inadequate employees development programmes had a positive influence on employees commitment in the area studied $(Z c=4.531>Z t=1.645)$. It was recommended that Organizations should regularly embark on performance appraisals because; it will go a long way to know whether the human capital development is producing the needed result and that there should be a systematic view towards employees' commitment development in organizations. That is to say all levels, sections should be given equal opportunity to develop. As generally stated, if you fail to plan, then you are planning to fail

KEYWORDS

Employees' commitment; organizational performance.
\end{abstract}

\section{INTRODUCTION}

In today's global market, companies are composed by competitors, regardless of industry. To develop a competitive advantage therefore, it is important that firms only leverage on the commitment of workforce as a competitive weapon. Most Organizations value commitment among their employees because it is typically assumed to reduce withdrawal behaviour, such as lateness, absenteeism and turnover. Hence, there is no doubt that these values appear to have potentially serious consequences for overall organizational performance. The study of employee commitment is important because; (Fisher, Lyle, and James (2006)), noted that employees with sense of employee commitment are less likely to engage in withdrawal behaviour and more willing to accept change. Hence, there is no doubt that these values appear to have potentially serious consequences for a core of committed individuals who are the source of organizational life; (b). Workers who become less committed to an organization, will route their commitment in other directions; thus, it is important to know how to develop the right type and level of employee commitment to ensure that the better employees are retained; (c). Employees who develop a high level of employee commitment tend to be highly satisfied and are fulfilled by their jobs; (d). In the current global economic scenario, organizational change is a continuous process that requires support of all employees in the hierarchical structure. 
Most organizations have realized that the performance of their workers plays a vital role in determining the success of the organization (Zheng, 2010; Ajila and Awonusi, 2004). As such, it is important for employers and managers alike to know how to get the best of their workers. One of the antecedent determinants of workers' performance is believed to be employee commitment (Ali, 2010; Ajila and Awonusi, 2004). As such, it is important for employers and managers alike to know how to get the best of their workers. Employee commitment has become one of the most popular work attitudes studied by practitioners and researchers. Akintayo and Tumwesigye (2010) noted that one of the reasons why commitment has attracted research attention is that organizations depend on committed employees to create and maintain competitive advantage and achieve superior performance.

A strategy for improving organizational performance is to drive higher value of commitment for employees. Firms seek to optimize their workforce commitment through comprehensive human capital development programmes not only to achieve business goals but most importantly as a long term survival and sustainability. To accomplish this undertaking, firms need to invest resources to ensure that employees have the knowledge, skills and competencies they need to work with commitment in a rapidly changing and complex environment

Furthermore, employees who share a commitment to the organization and their collective wellbeing are more suitable to generate the social capital that facilitates organizational learning. It is therefore important for organization to know the aspects that play important role or have big impact in boosting the commitment of their employees. Several factors had been identified in the literature as determinants of employee commitment. Some of the identified factors include; leadership style (Fisher, Lyle, and James, 2006); organizational fairness (Ponnu and Chuah, 2010); corporate social responsibility (Ali et al, 2010) etc Conclusively, it is generally believed that employee commitment is the engine room upon which the success of any organization is dependent; as a result, its relevance need not be over emphasized.

\section{Statement of The Problem}

With all of the focus in recent years on the need for organization to make them more competitive, there has been a remarkable lack of attention on the benefits of investing in employees' commitment. Employers are sometimes baffled when their highly-rated employees under-perform and others resign and leave the organization. Management fail to understand why some employees are not committed to the organization even though they have proactively implemented fair compensation policies and human resource (HR) practices to motivate and retain them. It can be costly if employees are not committed in their jobs, and if they lack the motivation to exercise their full potentials. While material costs, labour expenses, and other factors may be relatively comparable between different business entities, thus employee commitment offers organizations a real opportunity to differentiate themselves from the competition.

In view of the strategic role of identifying the variable that drives employees' commitment in the realization of organizational goals, it is necessary to identify key attributes of commitment that are lacking to address the challenge. But since employee commitment is the leverage that organizations need for a dynamic, innovative, and competitive workforce, it has become imperative to investigate the problems militating against employee commitment of Nigerian Beverage Industry and its performance. 


\section{Objectives of the Study}

1. To examine the impact of employee commitment on organizational profitability in brewing industry in Nigeria

2. To examine the dimensions of employee commitment on performance in brewing industry in Nigeria

\section{Research Questions}

1. To what extent does employee commitment a tool for organizational profitability in the brewing industry in Nigeria?

2. To what extent do dimensions of employee commitment an adequate tool for organizational performance in the brewing industry?

\section{Hypotheses}

1. There is no significant relationship between organizational profitability and employees' commitment in brewing industry in Nigeria.

2. There is no significant relationship between inadequate human capital and employees' commitment in the brewing industry in Nigeria.

\section{LITERATURE REVIEW}

Organizations value commitment among their employees because it is typically assumed to reduce withdrawal behaviour, such as lateness, absenteeism and turnover. Hence, there is no doubt that these values appear to have potentially serious consequences for overall organizational performance. The study of employee commitment is important because; a Lo (2009) noted that employees with sense of employee commitment are less likely to engage in withdrawal behaviour and more willing to accept change. Hence, there is no doubt that these values appear to have potentially serious consequences for a core of committed individuals who are the source of organizational life; (b). Workers who become less committed to an organization, will route their commitment in other directions; thus, it is important to know how to develop the right type and level of employee commitment to ensure that the better employees are retained; (c). Employees who develop a high level of employee commitment tend to be highly satisfied and are fulfilled by their jobs; (d). In the current global economic scenario, organizational change is a continuous process that requires support of all employees in the hierarchical structure.Most organizations have realized that the performance of their workers plays a vital role in determining the success of the organization (Zheng, 2010; Ajila and Awonusi, 2004). As such, it is important for employers and managers alike to know how to get the best of their workers. One of the antecedent determinants of workers' performance is believed to be employee commitment (Ali, 2010; Ajila and Awonusi, 2004). As such, it is important for employers and managers alike to know how to get the best of their workers.

\section{Concept of Organizational Performance}

According to the Wikipedia encyclopedia, performance is defined as the accomplishment of a given task measured against present known standard of accuracy, completeness cost and speed. Furthermore, the conceptual domain of organizational performance is limited to economic outcomes. On this basis, we identify four organizational performance dimensions: profitability, liquidity, growth, and stock market performance.

\section{Employee Development and Productivity}

It is well - known fact that the primary concern of an organization is its viability and hence its efficiency. For effective functioning of any organization, employees must learn to be committed and perform their job at a satisfactory level of proficiency and also the 
organization must provide opportunity for the continued development and training of employees not only on their jobs, but as well develop them for other jobs for which they might later be considered.

\section{Employees Commitment and Profitability}

According to the business dictionary profitability is defined as the quality or state of being profitable that is the capacity to make a profit from any business undertaking. Profit is total income or cash flow minus expenditures. This also means the money or other benefit a non - governmental organization or, individual receives in exchange for product and services sold at an advertised price. In the same vain investment in employees development is capital intensive and it can lead to increase in productivity of the organization and consequently high profitability. However, this can only be achieved if proper needs assessment is carried out. According to Imaga and Ewurum (2000), the bearing which employee's commitment has on profitability either direct or indirect is presented as follows:

(a) Increase in productivity through skill acquisition.

- The ultimate end of employee's development is to equip the organization members with requisite skills to become more productive and thereby increase the channels of increasing profitability. Considering the rate of technological changes, where new skills and techniques for production is on the increase, organizations need to undertake continuous training and development to remain competitive.

- Employee's commitment enhances the chances of professionalism and enhances motivation. It is quite obvious that a well - motivated worker will contribute his / her best towards organizational cause, which in the main, is profit. This motivation could come as a result of increases chances of career advancement and professionalism through human capital development.

- The cost of supervising highly developed employee is low thereby contributed to profitability positively. What happens in most organization where personnel are under - developed is that, more managerial time is spent on supervision and coaching and sometimes with little or no result. This is unlike a well-developed human capital who not only discharge his/her duties with minimal supervision but often time, add innovation and creativity to the work which in turn leads to increase productivity and profitability.

- Proper employee development saves the problem associated with supersession. There are firm that are held in bondage by few staff in strategic places in the organization. Those people knowing that their skills are rare within the organization start making unnecessary demand with threats of leaving if not met. Where they cannot actually stalemate the activities of their host organization, they inflict a deep wound to its profit target. This will not be the case where very many people are developed and succession adequately planned for.

- Systems such as budgetary control and application, performance appraisal, and compensation, other controls and feedback, which are sine qua non for enhanced profitability, can only be operated by personnel that are well developed and motivated. The foregoing buttresses the submission that employee development increases the chance of enhanced profitability of organizations.

\section{Motivation}

Motivation is defined as the process that initiates, guide, and maintains goal-oriented behaviors. Motivation is what causes us to act, whether it is getting a glass of water to reduce thirst or reading a book to gain knowledge. It involves the biological, emotional, social and 
cognitive forces that activate behavior. Motivation involves behavior that is active, purposive, and goal directed (Boume and Ekstrand, (1973). Most researchers agree that motivational levels affects performance through an energizing function. Thus the motivated individual is an active participant and will probably work harder as motivational levels increases. (Irwin, 1993). As noted earlier on principles of learning, the human capital must be motivated to learn.

\section{THEORETICAL FOUNDATION}

\section{Employees Theory}

The theory of employees is likened to human capital is rooted from the field of Macroeconomic development theory. (Schultz, 1993) Beckers (1993) Classic book, Human capital: A theoretical and Empirical analysis with special reference to education, illustrates this domain. Becker argues that, there are different kinds of capitals that include schooling, a computer training course, expenditures on medical care and infact, lectures on the virtues of punctuality and honesty are capital too.

In its true sense, they improved health, raised earnings, or add to a person's appreciation of literature over a lifetime. Consequently, it is fully in keeping with the capital concept as traditionally defined to say that expenditure on education, training, and Medicare, etc., are investment in capital. These are not simply costs but investment with valuable returns that can be calculated. From the perspective of classical economic theory, employees consider labour as a commodity that can be traded in terms of purchase and sales. This classical theory very much focuses on the exploitation of labor by capital. However, unlike the meaning traditionally associated with the term labor, employees refer to the knowledge, expertise and skills one accumulates through education and training.

Emphasizing the social and economic importance of employee's theory, Becker (1993) noted the most valuable of all capital is that investment in human beings. Becker distinguishes firm-specific employees from general-purpose employees. Examples of firmspecific employee include expertise obtained through education and training in management information systems, accounting procedures, or other expertise specific to a particular firm. General-purpose employees are knowledge gained through education and training in areas of value to a variety of firms such as generic skills in employee's development. Regardless of the application, Becker considers education and training to be the most important investment in employee's development and commitment. The figure below Presents the key relationship in employees theory and the assumptions underlying these relationships.

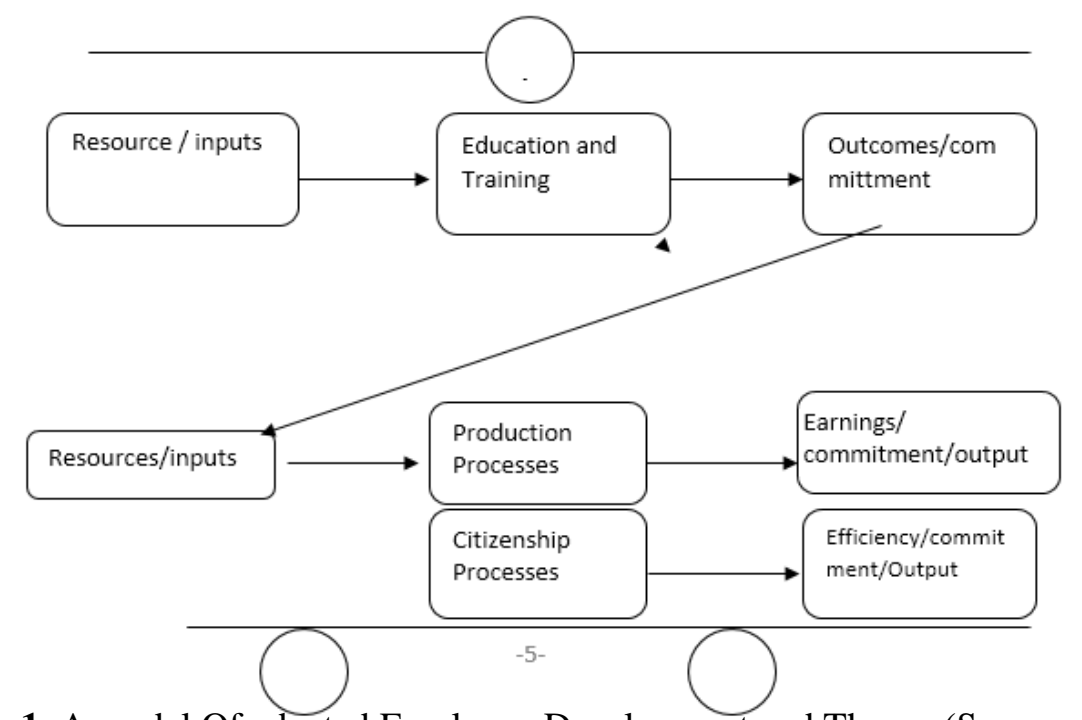

Figure 1. A model Of adapted Employee Development and Theory (Swanson 2001 
Relationship (1) represents the concept of production function as applied to education and training. The key assumption underlying this relationship is that, investment in education and training results in increased learning. Relationship (2) represents the employee's relationship between learning and increased productivity. The key assumptions underlying this relationship are that, increased learning does in-fact result in increased productivity. Relationship (3) represents the employee's development relationship between increased commitment, productivity and increased wages and business earnings. The key assumptions underlying this relationship are that greater productivity does in-fact result in higher wages and commitment for individuals and earnings for businesses. As per conclusion, employees do contribute in the organizational advantages and profit.

The entire employees continuum represented is assessed using return-on-investment analysis or cost-benefit analysis. The employee's development and commitment theory is an important agent for boosting firm's performance. Thus this study has capitalized on this theory for arguing that employee's development becomes an element in industrial performance.

\section{The Relationship between Employee Commitment and Firm Performance}

Employees focus on two main components which are themselves and organization. The concept has further been described by Garavan et al, (2001) that, employees have four key attributes as follows:

1. Flexibility and adaptability

2. Enhancement of individual competencies

3. The development of organizational competencies and

4. Individual employability.

It shows that, these attributes in turn generate, add value to individual and organizational outcomes.

\section{METHODOLOGY}

The study adopted a survey design. The population of this study consist of (250) employees of three breweries in Nigeria namely; Nigerian breweries Plc; Guinness breweries Plc. and champion Breweries Plc. drawn from key departments. These breweries are categorized into international, national, and local size firms. Sample size using Taro Yamani's statistical formula gave 216.The Pearson Products Moment Correlation B for the degree of relationship for reliability. Data presentation and analysis was done using the Z-test

\section{Data Presentation and Analysis}

Table 1. Respondents view on Employees Commitment Development programmes

\begin{tabular}{|l|l|l|l|l|l|l|}
\hline Statement & & SA & A & N & D & SD \\
\hline $\begin{array}{l}\text { Do you think you're your } \\
\text { organization believes in } \\
\begin{array}{l}\text { Employees commitment } \\
\text { programmes }\end{array}\end{array}$ & F & 100 & 60 & 10 & 20 & 16 \\
& $\%$ & 49 & 29.10 & 4.50 & 9.70 & 7.70 \\
\hline
\end{tabular}

Table 2. Respondents' perception of employees' commitment activities in their

\begin{tabular}{|l|l|l|}
\hline \multicolumn{2}{|c|}{ organizations } \\
\hline $\begin{array}{l}\text { Factors necessary for workers } \\
\text { commitment }\end{array}$ & Frequency & \% \\
\hline
\end{tabular}




\begin{tabular}{|l|l|l|}
\hline It is a means of satisfying mgt intent & 25 & 12.13 \\
\hline Mere jamboree & 15 & 7.28 \\
\hline No idea & 13 & 6.32 \\
\hline Total & 206 & 100 \\
\hline
\end{tabular}

Source: Fieldwork Analysis

From the table 4.2. above on the question on how respondents perceive employees commitment in the breweries surveyed, out of the 206 respondents, 153 of them representing $74.27 \%$ agreed that employees commitment development activities are necessary for workers, development while 25 respondents which account for $12.13 \%$ believes it is a means of satisfying management intent and 15 respondents accounting for $7.28 \%$ are of the opinion that they are mere jamboree, while 13 respondents accounting for $6.32 \%$ have no idea at all.

Table 3. Respondents view on organizational performance and employees' commitment programmes

\begin{tabular}{|l|l|l|}
\hline Factors & Frequency & \% \\
\hline Strongly agreed & 115 & 55.83 \\
\hline Agreed & 35 & 16.99 \\
\hline Neutral & 12 & 5.83 \\
\hline Disagree & 20 & 9.70 \\
\hline Strongly disagreed & 24 & 11.65 \\
\hline Total & $\mathbf{2 0 6}$ & $\mathbf{1 0 0}$ \\
\hline
\end{tabular}

Source: Fieldwork Analysis

From the about table $55.83 \%$ respondents agreed that organizational performance appraisal is a function of employees commitment development programmes, while $16.99 \%$ of respondents agreed that performance appraisal support HCD programmes also $5.83 \%$ of respondents are neutral and $9.70 \%$ disagreed while $11.65 \%$ strongly disagreed. The bottom line of the analysis is that, it could be deduced that from the three breweries surveyed, organizational performance appraisal is a function of employee's commitment.

\section{Hypothesis One: There is no significant difference between organizational profitability and employee's commitment in the brewing industry in Nigeria}

Table 4. The analysis of responses related to the First Hypothesis

\begin{tabular}{|c|c|c|c|c|c|c|c|}
\hline $\mathbf{s} / \mathbf{n}$ & Statement & & SA & $\mathbf{A}$ & $\mathbf{N}$ & D & SD \\
\hline \multirow[t]{2}{*}{1} & \multirow{2}{*}{$\begin{array}{l}\text { The investment in employees commitment } \\
\text { has a positive influence on organizational } \\
\text { profitability in the brewing industry }\end{array}$} & $\mathrm{F}$ & 117 & 56 & 10 & 11 & 13 \\
\hline & & $\%$ & 56.80 & 26.70 & 4.85 & 5.34 & 6.31 \\
\hline \multirow[t]{2}{*}{2} & \multirow{2}{*}{$\begin{array}{l}\text { Investment in employees commitment does } \\
\text { not have a positive effect on organizational } \\
\text { profitability of the brewing industry }\end{array}$} & $\mathrm{F}$ & 13 & 11 & 10 & 56 & 117 \\
\hline & & $\%$ & 6.31 & 5.34 & 4.85 & 26.70 & 56.80 \\
\hline \multirow[t]{2}{*}{3} & \multirow{2}{*}{$\begin{array}{l}\text { There is a relationship btw employees } \\
\text { commitment and organizational profitability } \\
\text { of the brewing industry }\end{array}$} & $\mathrm{F}$ & 119 & 53 & 8 & 12 & 14 \\
\hline & & $\%$ & 57.77 & 25.72 & 3.88 & 5.83 & 6.80 \\
\hline \multirow[t]{2}{*}{4} & \multirow{2}{*}{$\begin{array}{l}\text { There is no relationship btw employees } \\
\text { commitment and organizational profitability } \\
\text { of the brewing industry }\end{array}$} & $\mathrm{F}$ & 14 & 12 & 8 & 53 & 119 \\
\hline & & $\%$ & 6.80 & 5.83 & 3.88 & 25.72 & 57.77 \\
\hline
\end{tabular}

Source: Field work Analysis

Table 4.4. Shows that, for the statement that investment in employees' commitment has positive influence on organizational profitability on the brewing industry in the area studied. 
The responses are strongly agreed (SA) agreed (A) neutral (N) disagreed (D) and strongly disagreed (SD). They have frequencies of 117, 55, 10, 11, and 13 respectively out of 206. These gave percentage of $56.80,26.70,4.85,5.34$ and 6.31 respectively totaling 100 .

For the statement that investment in employees' commitment does not have positive effect on organisational profitability of the brewing industry in the area studied, the responses are strongly agreed (SA) agreed (A) neutral (N) disagreed (D) and strongly disagreed (SD). They have frequencies of $13,11,10,55$, and 117 respectively of 206 . They gave percentage of $6.31,5.34,4.84,26.70$, and 56.80 respectively totaling 100 .

For the statement that, there is positive relationship between investment in employees commitment and organizational profitability in the brewing industry in the area studied. The responses are strongly agreed (SA) agreed (A) neutral (N) disagreed (D) and strongly disagreed (SD). They have frequencies of 119, 53, 8, 12, and 14 respectively out of 206. These gave percentages of 57.77, 25.72, 3.88, 5.83 and 6.80 respectively totaling 100 .

For the statement that there is no relationship between investment in employees' commitment and organizational profitability on the brewing industry in the area studied. The responses are strongly agreed (SA) agreed (A) neutral (N) disagreed (D) and strongly disagreed (SD). They have frequencies of 14, 12, 8, 53, and 119 respectively out of 206. These gave percentages of $6.805 .83,3.8825 .72$ and 57.77 respectively totaling 100 .

\section{Hypothesis Two: There is no significant difference between inadequate employees commitment programme and organizational performance in brewing industry in Nigeria.}

Table 5. Analysis of responses related to hypothesis four

\begin{tabular}{|c|c|c|c|c|c|c|c|}
\hline $\mathbf{s} / \mathbf{n}$ & Statement & & $\overline{\text { SA }}$ & $\mathbf{A}$ & $\mathbf{N}$ & D & SD \\
\hline \multirow[t]{2}{*}{1} & \multirow{2}{*}{$\begin{array}{l}\text { Inadequate finance for employees } \\
\text { commitment has a positive influence on } \\
\text { organizational s performance in the } \\
\text { brewing industry }\end{array}$} & $\mathrm{F}$ & 120 & 54 & 9 & 11 & 12 \\
\hline & & $\%$ & 58.25 & 26.21 & 4.37 & 5.34 & 5.83 \\
\hline \multirow[t]{2}{*}{2} & \multirow{2}{*}{$\begin{array}{l}\text { Inadequate finance for employees } \\
\text { commitment does not have a positive } \\
\text { influence on organizational performance } \\
\text { in brewing industry }\end{array}$} & $\mathrm{F}$ & 12 & 11 & 9 & 54 & 120 \\
\hline & & $\%$ & 5.83 & 5.34 & 4.37 & 26.21 & 58.25 \\
\hline \multirow[t]{2}{*}{3} & \multirow{2}{*}{$\begin{array}{l}\text { There is a relationship between } \\
\text { inadequate finance for employees } \\
\text { commitment and organizational } \\
\text { performance in the brewing industry }\end{array}$} & $\mathrm{F}$ & 124 & 50 & 10 & 12 & 10 \\
\hline & & $\%$ & 60.19 & 24.27 & 4.85 & 5.83 & 4.85 \\
\hline \multirow[t]{2}{*}{4} & \multirow{2}{*}{$\begin{array}{l}\text { There is no relationship between } \\
\text { inadequate finance for employees } \\
\text { commitment and organizational } \\
\text { performance in the brewing industry }\end{array}$} & $\mathrm{F}$ & 10 & 12 & 10 & 50 & 124 \\
\hline & & $\%$ & 4.85 & 5.83 & 4.85 & 24.27 & 60.19 \\
\hline
\end{tabular}

Source: Field work Analysis

Table 4.5 shows that for the statement that inadequate finance for employees commitment has a positive influence on organizational performance in the brewing industry the response are strongly agreed (SA) agreed (A) neutral (N) disagreed (D) strongly disagreed (SD). They have frequencies of $117,55,10,11$ and 13 respectively out of 206 . These gave percentage of 56.80. 26.70, 4.85, 5.34, and 6.31 respectively totaling 100 .

For the statement that inadequate finance for employees commitment does not have positive influence on organisational performance in the brewing industry, the response are strongly agreed (SA) agreed (A) neutral (N) disagreed (D) strongly disagreed (SD) these gave percentages of 5.38, 5.34, 4.37, 26.21 and 58.25 respectively totaling 100 . 
For the statement that there is a relationship between inadequate finance for employees commitment on organisations performance in the brewing industry the response are strongly agreed (SA) agreed (A) neutral (N) disagreed (D) strongly disagreed (SD). They have frequencies of 124, 50,10,12 and 10 respectively out of 206. These gave percentage of $60.19,24.27,4.85,5.83$ and 4.85 respectively totaling 100 .

For the statement that there is no relationship between inadequate finance for employees commitment on organizational performance in the brewing industry in the area studied, the response are strongly agreed (SA) agreed (A) neutral (N) disagreed (D) strongly disagreed (SD). They have frequencies of $10,12,10,50$, and 124 respectively out of 206 . These gave percentage of 4.85, 5.83, 4.85, 24.26 and 60.19 respectively totaling 100 .

\section{Verification of Hypotheses}

The statistical tool that was used to test the above hypotheses is Z-test of population proportion state below

$$
\mathrm{Z}=\frac{\frac{x}{n}-P o}{\sqrt{\frac{(P o)(1-P o)}{n}}}
$$

Where $\mathrm{x}=$ the number of respondents which strongly agreed or agreed with the statement that corresponds to the first alternate hypothesis

$$
\begin{aligned}
& \mathrm{n}=\text { the sample size } \\
& \mathrm{Po}=\text { the prescribed proportion }
\end{aligned}
$$

Level of significance for testing the hypotheses was $5 \%$

\section{Decision Criteria}

Reject Ho if $\mathrm{Zo}>\mathrm{Zc}$

Testing hypothesis One

Table 6. Shows the computational details of the 1st hypothesis

\begin{tabular}{|l|c|lc|l|l|}
\hline Statement & $\mathbf{x} / \mathbf{n}$ & $\begin{array}{l}\text { Calculated Z- } \\
\text { value }\end{array}$ & Table Z value & $\begin{array}{l}\text { Statistical } \\
\text { decision }\end{array}$ \\
\hline $\begin{array}{l}\text { Investment in emplo- } \\
\text { yees commitment } \\
\text { affects organisa } \\
\text { tional profitability in } \\
\text { the brewing industry }\end{array}$ & $\frac{173}{206}$ & 4.226 & 1.645 & $\begin{array}{l}\text { Reject } \\
\text { Ho }\end{array}$ \\
\hline
\end{tabular}

$\mathrm{NB}: \frac{Z=\frac{x}{n}-P o}{\sqrt{\frac{(P o)(1-P o)}{n}}}$

Where $\mathrm{x}=$ the number of respondents which strongly agreed or agreed with the statement that corresponds to the third alternate hypothesis

$$
\begin{aligned}
& \mathrm{n}=\text { the sample size } \\
& \mathrm{Po}=\text { the prescribed proportion }
\end{aligned}
$$

So for $\mathrm{x}=173, \mathrm{n}=206, \mathrm{Po}=0.7$ and $1-\mathrm{Po}=0.3$

$$
Z=\frac{\frac{x}{n}-P o}{\sqrt{(P o)(1-P o)}}
$$




$$
\begin{aligned}
Z= & \frac{\frac{173}{206}-0.7}{\sqrt{(0.7)(0.3)}} \\
Z= & \frac{\sqrt{206}}{\sqrt{206}}(0.8398058-0.7) \\
Z=\sqrt{0.2} & (0.1398058-0.7)) \\
Z & \sqrt{0.2} \\
Z= & \frac{14.3527}{0.4582575} \quad(0.1398058) \\
Z= & (31.320163)(0.1398058) \\
Z & =4.3787404 \\
Z & =4.379 \text { to } 3 \text { decimal places }
\end{aligned}
$$

From Table 6 above, it is shown that, the calculated $Z$ value is 4.379 to 3 decimal places. The table $Z$ value at $5 \%$ level of significance is 1.645 . Since the calculated $Z$ value is greater than the table value, the null hypothesis is rejected and the alternate hypothesis is accepted at $5 \%$ level of significance. This shows that investment in employee's commitment development has a positive influence on the organizational profitability of the brewing industries studied

\section{Testing Hypothesis Two}

Table 7. Shows the computational details of the 2nd Hypothesis

\begin{tabular}{|l|l|l|l|l|}
\hline Statement & $\mathbf{x} / \mathbf{n}$ & $\begin{array}{l}\text { Calculated Z- } \\
\text { value }\end{array}$ & Table Z value & $\begin{array}{l}\text { Statistical } \\
\text { decision }\end{array}$ \\
\hline $\begin{array}{l}\text { Inadequate fund for } \\
\text { employees development } \\
\text { affect } \\
\text { performance in the brewing } \\
\text { industries studied }\end{array}$ & $\frac{174}{206}$ & 4.531 & 1.645 & $\begin{array}{l}\text { Reject } \\
\text { Ho }\end{array}$ \\
\hline
\end{tabular}

$\mathrm{NB}: \frac{Z=\frac{x}{n}-P o}{\sqrt{\frac{(P o)(1-P o)}{n}}}$

Where $\mathrm{x}=$ the number of respondents which strongly agreed or agreed with the statement that corresponds to the fourth alternate hypothesis

$$
\begin{aligned}
& \mathrm{n}=\text { the sample size } \\
& \mathrm{Po}=\text { the prescribed proportion }
\end{aligned}
$$

So for $\mathrm{x}=174, \mathrm{n}=206, \mathrm{Po}=0.7$ and $1-\mathrm{Po}=0.3$

$$
\begin{aligned}
& Z=\frac{\frac{x}{n}-P o}{\sqrt{(P o)(1-P o)}} \\
& Z=\frac{\frac{174}{206}-0.7}{\sqrt{(0.7)(0.3)}} \\
& Z=\sqrt{206} \\
& \quad(0.8446601-0.7)
\end{aligned}
$$




$$
\begin{aligned}
& \sqrt{0.2} \\
Z=\sqrt{206} \quad(0.8446601-0.7) & \sqrt{\overline{0.2}} \\
Z= & \frac{14.3527}{0.4582575}(0.1446601) \\
Z= & (31.320159)(0.1446601) \\
Z & =4.5307779 \\
Z & =4.531 \text { to } 3 \text { decimal places }
\end{aligned}
$$

From table 4.3 .4 above, it is shown that, the calculated $\mathrm{Z}$ value is 4.531 to 3 decimal places. The table $\mathrm{Z}$ value at $5 \%$ level of significance is 1.645 . Since the calculated $\mathrm{Z}$ value is greater than the table $\mathrm{Z}$ value, the null hypothesis is rejected and the alternate is accepted at $5 \%$ level of significance. This shows that inadequate fund for employees development affects organizational performance in the brewing industries studied.

\section{DISCUSSION OF FINDINGS}

1. An effective and efficient employee's commitment development leads to organizational profitability. In the words of Imaga and Ewurum (2000), the bearing which employees' development has on organizational profitability either directly or indirectly is so high that, the employees must be adequately trained and retrained in order to attain organizational objectives and goals. In line with this assertion, it was observed from the third hypothesis that, investment in employees' commitment has a positive influence on organizational profitability in the brewing industries studied.

2. In the assessment of employee commitment development of Nigerian Brewing Industry with a view to determine the extent to which financial constraints impede human capital development. It was discovered that finance is a major problem to the development of employees' development.

3. The analyses second hypothesis postulate that financial handicaps impede the development of quality employees in Nigeria Brewing Industry. In the word of Ubeku (1992), most organizations in Nigeria consider employees commitment development as an expensive venture and avoid it like a plague. This according to him and many pundits of our time is false. Because this is further confirmed by organizations that have effectively and efficiently used employees development programs to advance the course of their organizations performance. However, due to the importance attached to employees commitment development and its associated cost, organization have fashioned out ways of delivering cost effective employee development programs.

4. Generally, it was discovered that a large number of staff of the three organizations are middle age skillful making about $82 \%$ of the sample size. This has contributed to the productivity and growth achieved by these organizations. The staff strength that is titled on the middle age population which is intellectually and technically competent has mainly helped the three organizations to improve productivity.

5. We equally observed that the human resources managers of the three organizations investigated places high premiums on employees commitment development in order to attain organizational objectives and goals. 
6. In this regards, staff are intermittently selected to attend institutions like staff colleges as well on-the-job and off-the-job training programs. While in some cases Symposia and Seminars are occasionally organized in order for staff to be abreast with best global practices in operations. This unveils the relevance of employee commitment development in any organization as it enhances organizational performance and efficiency.

\section{CONCLUSION}

Conclusively, the contribution of the employees commitment to the economic growth and survival of every organization cannot be over emphasized. Indeed, the employees commitment element is the ultimate in all the factors of production in any organization; hence it must be developed for ultimate performance and enhance organizational performance in diverse areas.

To this end, organizations are beginning to accept the importance of utilizing and developing the potentials of their employee as a means of enhancing competitive capability

For instance, Nigerian Brewing and Guinness Nigerian Plc. are very consistent in their employees commitment development programmes unto the extent that workers are sent abroad on training, while Champion Breweries Plc. is seriously affiliated to Nigeria Breweries in the area of training too. There is therefore the realization that, no matter how good and sophisticated the technology may be, it is little relevance to the organization's goals when managed and operated by under-developed employees.

With the current global technology revolution, employees commitment development will continue to occupy its place in the agenda of serious organizations with even more attention to enable organizations meet the challenges of the 21st Century. Most successful organization will be those that manage employees in the most effective and efficient manner, which is concomitant to increase organizational performance. Since employees commitment development is the leverage that organizations need for a competitive and innovative work force, managements are therefore advised to generally adopt it as a strategy that will enhance staff performance and organizational efficiency and effectiveness.

\section{RECOMMENDATIONS}

1. It is permanent to note that the benefit of employees commitment development can be enjoyed by all forms of organizations, whether government or even one man business. Therefore no organization should show lukewarm attitude towards employees' commitment development, rather they should enhance and embrace it.

2. Employees commitment development and performance appraisal are inextricably likened. It is therefore recommended that organizations should regularly embark on performance appraisals because; it will go a long way to know whether the human capital development is producing the needed result.

3. It is equally recommended that there should be a systematic view towards employees commitment development in organizations. That is to say all levels, sections should be given equal opportunity to develop.

4. Generally, it is recommended that employees commitment development programmes should be in line with the policies and objective of the organization. It should not be promoted by spontaneity but at the instance of the need and objective of the organization. Planining is also very key.

\section{REFERENCES}

Akintayo and Tumwesigye (2010), Human Resource Management, Theory and Practice.Butter Worth Heineman. 
Anyawu, P. (1984), Managing Human Assets .Benin City: Etheope Publishing Corporation

Aneke. E. U. (1998), Introduction to Academic Research Methods. Enugu: Gostark Printing and Publishing Company Ltd

Boume, D. and Ekstrand G. (1998), Fundamentals of Management, George: Alan and Unwin Limited.

Enugu: Precision Printers and Publishers.

Ewurum, U. F. F. and Unamka, P. C. (1995), Business Administration Financial Times Pitman Publishing.

Ewurum, U. F. F. (2005), Notes on Analytical Techniques and Operations Research. MSc/Ph.D Class UNEC (unpublished).

Fisher, D. C., Lyle, F. S. and James, B. S. (2006), Human Resource Management.

Ikeagwu E. K. (1998), Groundwork on Research Methods and Procedures Enugu: IDS UNEC, University Press.

Imaga, U. and Ewurum U.J. (2004), Intellectual Capital Enugu: Otek Publishing

Imaga, E. U. L. and Ewurum, U. F. F. (2000), Business Management. Topic Vol. 2

Irwin, I. G. (1993), Training in Organization Need Assessment, Development and Evaluation. Italy: ISEP Press

Mills, G.H and Walter, J.A (1998) Technical writing. New York: Hot. Rinehart and Winston

Podsakoff, P.W. and Dalton, D.R. (1998) Researcher Methodology in organization. Journal of Management. Volume B.

Ponnie F. W. and Chauh G,H(2010), Managing Human Resource Productivity, Quality of Work Life, Profit.

Spiegel, M.R. (1992) Scharm's Outline Theory and Problems of Statistics. New York: McGraw Hill Book Company

Spiegel, R.M. and Stephens J.L. (1990) Statistics, Singapore, Mc Graw-Hill press.

Schultz, C. A. (1993), Modern Business Administration; Great Britain San Francisco: Jossy Base Shaun, T. and Alfred (2000), Essentials of Human Resource Management, Auckland, Great Britain:

Taro Yemmani (1964), Trend in Business Studies Statistics London: Longman Publishers. 